\title{
Clinical Features and Quality of Life in Duchenne and Becker Muscular Dystrophy Patients from A Tertiary Center in Turkey
}

\section{Türkiye'de Üçüncül Bir Merkezden Duchenne ve Becker Müsküler Distrofili Hastaların Klinik Özellikleri ve Yaşam Kalitesi}

\author{
Özlem Yayıcı Köken (0000-0003-2112-8284), Özge Kucur* (0000-0002-6597-4549), \\ Candan Taşkıran** (0000-0001-6116-2730), Ülkühan Öztoprak* (0000-0002-7309-3215), \\ Çiğdem Genç Sel*** (0000-0002-3644-3124), Erhan Aksoy* (0000-0002-7210-6715), \\ Ayse Aksoy**** (0000-0001-7533-1638), Tamer Yoldaş***** $(0000-0002-5086-6625)$, \\ Deniz Yüksel* (0000-0001-8990-023X) \\ Ankara City Hospital, Childrens' Hospital, Clinic of Pediatric Neurology, Ankara, Turkey \\ *University of Health Sciences Turkey, Dr. Sami Ulus Maternity and Children's Health and Diseases Research and Training Hospital, \\ Clinic of Pediatric Neurology, Ankara, Turkey \\ **University of Health Sciences Turkey, Dr. Sami Ulus Maternity and Children's Health and Diseases Research and Training Hospital, \\ Clinic of Child and Adolescent Psychiatry, Ankara, Turkey \\ ***Medical Faculty of Ufuk University, Department of Pediatric Neurology, Ankara, Turkey \\ ${ }^{\star * \star \star}$ Medical Faculty of Samsun Ondokuz Mayıs University, Department of Pediatric Neurology, Samsun, Turkey \\ *****University of Health Sciences Turkey, Dr. Sami Ulus Maternity and Children's Health and Diseases Research and Training Hospital, \\ Clinic of Peditric Cardiology, Ankara, Turkey
}

Keywords

Duchenne musküler distrofi, becker musküler distrofi, sağlıkla ilişkili yaşam kalitesi

\section{Anahtar kelimeler \\ Duchenne muscular dystrophy, becker muscular dystrophy, health-related quality of life}

Received/Geliş Tarihi : 28.06.2020

Accepted/Kabul Tarihi : 15.01.2021

DOI:10.4274/jcp.2021.0003

Address for Correspondence/Yazışma Adresi (Sorumlu Yazar):

Özlem Yayıı Köken MD, Ankara City Hospital, Childrens' Hospital, Clinic of Pediatric Neurology, Ankara, Turkey

\begin{abstract}
Introduction: Duchenne Muscular Dystrophy (DMD) and Becker Muscular dystrophy (BMD), are chronic and progressive and rare genetic disorders that cause systemic involvement such as progressive muscle deterioration, motor disability, cardiomyopathy, and respiratory problems, with an increased risk of cognitive decline and psychological problems They are a group of neuromuscular diseases in which psychological problems affect negatively on quality of life (Qol) not only patients but also caregivers. This study demonstrates the clinical features of patients with DMD/BMD and their caregivers and compares controls with respects to psychological and social aspects.

Materials and Methods: A total of 20 patients (3 with BMD and 17 with DMD), aged between 8 and 18 years, and 20 age-matched healthy children were included in this descriptive and cross-sectional study. The patients were evaluated by the pediatric neurology, cardiology, and psychiatry departments at the study time. Their demographic and clinical features were recorded. The Wechsler Intelligence Scale for Children-Revised (WISC-R), Pediatric Quality of Life Inventory (PedsQL) and its parent form, and the Strengths and Difficulties Questionnaire (SDQ) were applied to all of the participants.

Results: The QoL scores were lower in patients with moderate and severe DMD/ BMD and their caregivers. In patients with DMD and in both groups, emotional symptoms, peer problems and prosocial behavior scores were higher in the subsets of the SDQ. The PedsQL child-parent scores were lower in all of the subsets with statistical significance.

Conclusions: DMD and BMD comprise a group of chronic diseases with multiple complications that are difficult to manage. A QoL equal or close to that of the healthy children should be targeted. Today, proposed or experimental treatments for this disease group are assessed based on their ability to enhance QoL. Inquiring into the QoL and counseling should become routine.
\end{abstract}


$\ddot{O} \mathbf{z}$

Giriş: Duchenne ve Becker musküler distrofi (DMD,BMD); progresif kas güçsüzlüğü, motor beceriksizlik, kardiyomyopati ve r solunumsal problemler, artmış bilişsel kayıp riski ve psikolojik problemler gibi sistemik bulgularla seyreden kronik, progresif seyirli, nadir genetik bozukluklardır. Bu nöromusküler hastalık grubunda yalnızca hastaların değil bakımverenin de yaşam kalitesinin negatif yönde etkilendili psikolojik problemlerin eşlik ettiği durumlardır. Bu çalışmada; DMD/BMD hastalarınnın klinik özellikleri yanısıra hastalar ve bakımverenlrin psikolojik ve sosyal etkileninmleri ortaya konulmaya çalışılmıştır.

Gereç ve Yöntem: 3'ü BMD, 17'si DMD tanılı, 8-18 yaş aralığındaki 20 hasta ile age-matched 20 sağlıklı control çalışmaya dahil edilerek tanımlayıcı ve kesitsel bir çalışma planlanmıştır. Hastalar; çocuk nörolojisi, çocuk kardiyolojisi ve çocuk psikiyatrisi tarafından eş zamanlı değerlendirilmiştir. Demografik ve klinik özellikleri kaydedilmiştir. Çocuklar için revize edilmiş Wechsler zeka ölçeği,Çocuklar ve ebeveynler için yaşam kalitesi ölçeğ ve Güç ve Güçlükler Anketi hasta ve kontrol grubuna uygulanmıştır. Bulgular: Klinik ciddiyeti orta ve ciddi olan DMD/BMD hastalarında sağlıklı kontrollerle karşılaştırıldığında hem hasta hem bakımverenin QOL skorları oldukça düşük saptandı. SDQ’ya göre ise alt içerikler açısından hem tüm grupta hem de DMD tanılı hasta grubunda emosyonel symptoms, peer problems ve social behavior açısından sağlıklı kontrollere göre yüksek skorlar elde edildiği başka bir deyişle bu alanlarda negative yönde belirgin etkilenme olduğu görüldü. PedsQL child-parent skorları tüm alt başlıklarda sağlıklı kontrollere göre istatistiksel önemlilikle birlikte düşük saptanmıştı.

Sonuç: DMD/BMD yönetmekte güçlük yaşanan çok sayıda komplikasyonu olan bir grup kronik hastalıktır. Yaşam kalitesinin sağlıklı çocuklar kadar veya onlara yakın bir düzeyde tutulması hastalık yönetiminin ana hedefi olmalıdır. Günümüzde bu hastalık grubundaki önerilen veya henüz deneme aşamasındaki tedaviler de yaşam kalitesinin arttırılması ön koşulu ile değerlendirilmektedir. Bu nedenle; klinik pratikte sağlık hizmetleri yanısıra yaşam kalitesinin sorgulanması ve arttırıcı önerilerin verilmesi bir rutin olmalıdır.

\section{Introduction}

Duchenne muscular dystrophy (DMD) and its allelic form Becker muscular dystrophy (BMD) are common hereditary neuromuscular diseases with an X-recessive pattern caused by a mutation in the dystrophin gene, which encodes the dystrophin protein found in skeletal muscle, cardiac muscle, and brain and results in a deficiency or absence of sarcolemmal dystrophin $(1,2)$. The deficiency or absence dystrophin causes multisystem involvement resulting in various comorbidities. Psychosocial problems associated with chronic diseases have become an important part of disease management owing to better care options and increasing life expectancy (3). A drop in Weschler Full Scale IQ scores when compared to the normal population has been reported in both DMD, which is characterized by the absence of dystrophin, and BMD, which is characterized by the deficiency of dystrophin (4). Additionally, problems concerning memory and reading, behavioral issues, and deficits in problem solving have been widely reported in both DMD and BMD (4). In patients reaching adulthood, the effect on cognitive functions, and social, emotional and behavioral functionality will become more pronounced (3). Another important point of concern is the quality of life (QoL) of these patients, who are dependent on their caregivers since no definitive therapy has been found.
The aim of this prospective, questionnairesupported, desciriptive and cross-sectional study was to investigate the intellectual capacity, and emotional, social and behavioral functionality in addition to QoL in pediatric patients with a diagnosis of DMD or BMD. Some prominent aspects, which should be an important part of disease management but are usually overlooked in clinical practice, have been tried to emphasize.

\section{Materials and Methods}

Ethics committee approval was obtained from the institutional ethics board of the Ankara Children's Hematology-Oncology Training and Research Hospital Ethics Committee (2018-2003). Written informed consent was obtained from both the children and parents who participated in the study. This descriptive, cross-sectional study was conducted on patients between 8 and 18 years of age who were diagnosed with dystrophinopathy at the University of Health Sciences Turkey, Dr. Sami Ulus Maternity and Children's Health and Diseases Research and Training Hospital, Department of Pediatric Neurology between 2013 and 2018.

\section{Participants and Evaluations}

The inclusion criteria were: 1) confirmed diagnosis of dystrophinopathy by molecular genetic analysis, 
2) patients and parents providing written informed consent to participate in the study, 3) availability of a primary caregiver to complete the parent questionnaire, and 4) a minimum follow-up period of 2 years in our clinic. As a result, 3 patients with BMD, 17 patients with DMD, and 20 healthy age- and sex-matched volunteers were included in the study (flowchart) (Figure 1).

Demographic and clinical data, follow-up features, and genetic examination results of the patients were obtained from the patient files. Muscle strength, ambulatory status, wheel-chair dependency, need for ventilator support, steroid usage, and the existence of scoliosis in all of the patients were cross-sectionally recorded. Physical examination for muscle strength was performed according to the Medical Research Council Scale for assessing muscle strength. This scale ranged between 0 and 5, and was reliable when applied by the same professional or by members of a well-trained and experienced group of professionals, and thus was performed by a single experienced clinician (Ö.K.) in this study. A positive Gower's sign, difficulty in climbing stairs, and/or the existence of a waddling gait was accepted as moderate, while the inability to rise without assistance, less than or equal to a grade of $3 / 5$ strength in major muscle groups by manual muscle testing (according to the Medical Research Council 5-point scale), ambulation only with effort, severe wasting of muscles, and/or wheelchairdependent patients were accepted as severe (4).

Cardiacevaluationsincludingelectrocardiographic and echocardiographic studies performed during the study were also recorded. Patients and their families were evaluated by a pediatric and adolescent psychiatrist (C.T.). A total of 12 patients were able to complete the Wechsler Intelligence Scale for Children-Revised (WISC-R), 2 patients who were under age of 6 were evaluated using the StanfordBinet test. In other patients, their cognitive status and presence of the diagnosis of intellectual disability were evaluated by the child and adolescent psychiatrist. Patients older than 8 years were evaluated using the Pediatric Quality of Life Inventory (PedsQL), which they completed themselves, while their parents completed and were evaluated by the Strengths and Difficulties Questionnaire (SDQ) and the PedsQL. The WISC-R, PedsQL, and SDQ were applied to 20 healthy children of the same age group, thus forming the control group.

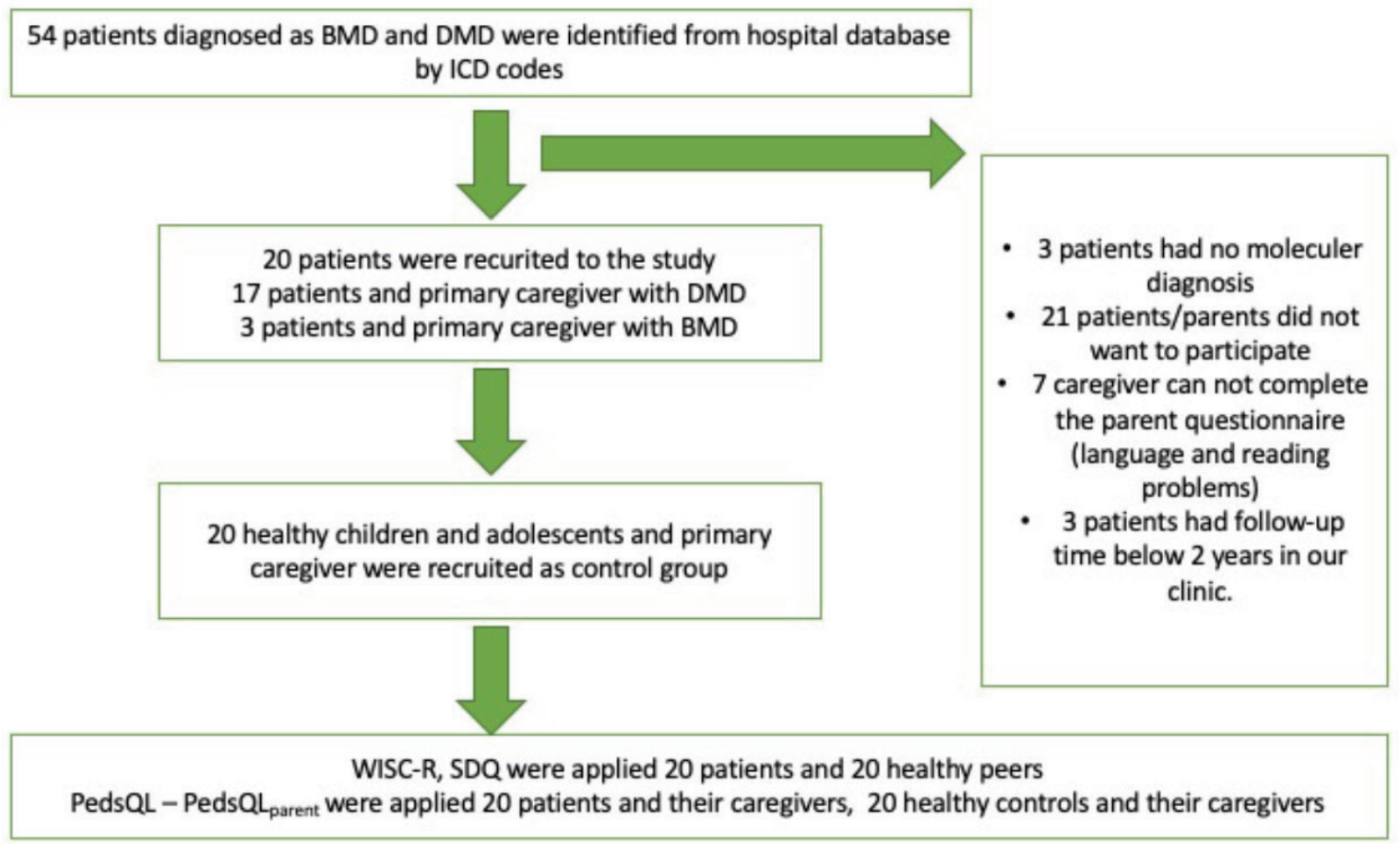

Figure 1. As a result, 3 patients with BMD, 17 patients with DMD, and 20 healthy age- and sex-matched volunteers were included in the study. 


\section{Tests and Questionnaires Used in the Study}

\section{Wechsler Intelligence Scale for Children-Revised (WISC-R)}

The WISC-R was individually applied to children between 6 and 16 years of age and took approximately $90 \mathrm{~min}$ for them to finish. It consisted of 12 subtests comprising 6 verbal (information, similarities, arithmetic, vocabulary, and comprehension digit span) and 6 performance (picture completion, picture arrangement, block design, object assembly, coding, and mazes) scales. There were 3 categories that were graded: verbal, performance, and overall intelligence. Patients were conventionally classified as: I) severely mentally retarded if their IQ was below 50 or impossible to assess because of pronounced behavioral disturbances; II) mildly mentally retarded (IQ between 50 and 70); III) borderline (IQ between 71 and 84 ), and IV) normal (IQ>85 or strictly normal academic level) $(5,6)$.

\section{Strength and Difficulties Questionnaire (SDQ)}

This scale, which was developed by Goodman, was used to evaluate the strengths and problem behaviors of the individuals (7). It consisted of 25 questions that were divided into 5 subscales: 1) emotional symptoms, 2) conduct problems, 3) attention deficit and hyperactivity, 4) peer relationship problems, and 5) prosocial behavior. Every subscale was evaluated in itself and the sum of the first 4 subscales provided the total difficulty score. The total points could vary between 0 and 40. A higher score, except in the prosocial category, signified a problem in that category. Low-, moderate-, or high-risk emotional disturbances (anxiety, depression, etc.), behavioral disturbances, and hyperactivity and attention deficit disorders, based on DSM-IV or ICD-10, could be estimated based on the results. Accordingly, $25 \%-60 \%$ of the patients in the high-risk group, $10 \%-15 \%$ of the patients in the moderate-risk group, and $1 \%-4 \%$ of the patients in the low-risk group were diagnosed with associated disorder. The validity and reliability study of this test was performed by Güvenir et al. (8).

\section{PedsQL - Peds $Q L_{\text {parent }}$}

The PedsQL is a tool for the measurement of life quality, which was developed by Varni et al. in 1999, after 15 years of work that measured the QoL in children and adolescents between 2 and 18 years of age. It can be completed in approximately 5-10 min and is widely used by researchers due to its ease of use and grading. This questionnaire is focused on the past month of the patient's life. The form prepared for the parents measures the QoL of the patient according to the parent. This scale was developed by Varni in 2004 to measure the effects that having a child with the disease had on families. The questionnaire evaluates physical health, and emotional and social functionality, which are the features of healthiness described by the World Health Organization (WHO). Functionality in school is also evaluated. Grading is done in 3 areas. The psychosocial health summary score is calculated using the sum of 3 points; total psychosocial health points are calculated by adding the scale total score first, physical health total score next, and points from emotional, social and academic functionality last. This questionnaire was developed as a Likert-type scale consisting of questions with 3 choices for children between 5 and 7 years old, and 5 choices for children between 8 and 18 years. In this QoL scale, which consists of 23 items, every item is graded between 0 and 100, where 100 means never, 75 means rarely, 50 means sometimes, 25 means often, and 0 means almost always. The higher the total PedsQL score, the better the QoL associated with health (9).

\section{Statistical Analyses}

Data analyses were performed using SPSS for Windows v.22.0 (IBM Corp., Armonk, NY, USA). Whether the distribution of continuous variables was normal or not was determined by the Kolmogorov Smirnov test. The Levene test was used for evaluation of the homogeneity of the variances. Unless specified otherwise, continuous data were described as the mean \pm SD for normal distributions, and median (range) for skewed distributions. Categorical data were described as the number of cases (\%).

Statistical analysis differences in normally distributed variables between 2 independent groups were compared by the Student's t test, and the Mann Whitney $U$ test was applied for comparisons of the not normally distributed data. While differences in the normally distributed variables among more than 2 independent groups were analyzed by 1-way ANOVA, 
the Kruskal Wallis test was applied for comparisons of the not normally data. When the P-value from the 1-Way ANOVA or Kruskal Wallis test statistics was statistically significant, the post hoc LSD or Conover's non-parametric multiple comparison tests were used to determine which group differed from which others. Statistical significance level is accepted as $\mathrm{p}<0.05$.

\section{Results}

Of the 20 patients that were evaluated, 17 had DMD and 3 had BMD. All of the patients were males except for one female patient who had a diagnosis of symptomatic DMD.The average age of the patients was $133.5 \pm 21.4$ months at the time of enrollment.
Table 1 summarizes the demographical and clinical datas of the patricipants.

All of the patients had elevated creatinine kinase levels (greater than 5 times the normal level) on admission. Histopathological examination of the muscle biopsies revealed dystrophic changes and a deficiency or absence of dystrophin in 13 patients. All of the clinical and histopathological findings were confirmed using genetic studies. Multiplex ligation-dependent probe amplification (MLPA) was the technique of choice for the genetic studies, which revealed deletion in the dystrophin gene in 16 patients (80\%) and duplication in the same gene in 3 patients. A nonsense mutation was found as a result of gene sequencing in 1 patient who did not have any

Table 1. The demographical and clinical datas of the participants

\begin{tabular}{|c|c|c|}
\hline & $\operatorname{BMD}(n=3)$ & $\operatorname{DMD}(n=17)$ \\
\hline The average age at the onset of symptoms (mo) & $105.6 \pm 12.3$ & $53.3 \pm 22.7$ \\
\hline \multicolumn{3}{|l|}{ Complaints on admission } \\
\hline Positive family history $(\mathrm{n}=5)$ & - & 5 \\
\hline Muscle weakness $(n=13)$ & 3 & 11 \\
\hline Motor delay $(n=15)$ & - & 15 \\
\hline Toe-walking & 2 & 4 \\
\hline Poor head control & - & 3 \\
\hline Inability to jump & 1 & 2 \\
\hline Frequent falls & 2 & 11 \\
\hline Difficulty in climbing stairs & 3 & 3 \\
\hline Difficulty in running & 3 & 4 \\
\hline Abnormal liver function tests & 1 & 5 \\
\hline Calf hypertrophy & 1 & 14 \\
\hline \multicolumn{3}{|l|}{ Ambulation status } \\
\hline Ambulatory-independently & 2 & - \\
\hline Ambulatory with restrictions & 1 & 10 \\
\hline Required assistance & - & 7 \\
\hline The average age of using a wheelchair & - & $106.7 \pm 22.1$ \\
\hline The average age at the onset of complete loss of ambulation & - & $145 \pm 21.2$ \\
\hline \multicolumn{3}{|l|}{ Intellectual disability } \\
\hline None & 3 & 6 \\
\hline Mild & - & 5 \\
\hline Moderate & - & 2 \\
\hline Learning disability & 1 & 2 \\
\hline \multicolumn{3}{|l|}{ Regular Treatments } \\
\hline Corticostreoids & - & 17 \\
\hline
\end{tabular}


mutations on MLPA. The only female patient had a heterozygous 6-7 exon deletion in the dystrophin gene (MLPA result) and this symptomatic patient was being followed-up with a DMD diagnosis.

While all of the BMD $(n=3)$ patients were ambulatory, 2 had more prominent difficulty running, climbing stairs, and exercising (mild clinical severity). One 17-year-old DMD patient who is not ambulatory for 11 years had cardiomyopathy, valvular regurgitation, and an ejection fraction (EF) of $42 \%$. The patient had been taking oral enalapril for 34 months. Another patient with DMD had only cardiomyopathy with an EF of $65 \% .13$ patients $(65 \%)$ were receiving Vitamin D treatments due to 25-hydroxyvitamin D levels below $30 \mathrm{ng} / \mathrm{mL}$. All of the patients were in physiotherapy follow-up.

The WISCR results of the BMD patients $(n=3)$ were as follows: verbal IQ $74.0 \pm 14.3$, performance IQ $98.7 \pm 2.7$, and total IQ $84.7 \pm 12.6$. When compared to the DMD group, the BMD group had higher scores in all 3 areas and there were no scores below 70, except for 1 patient who had a verbal IQ of 60 . For the WISCR results, the only statistically significant lower scores of the DMD patients were in the performance IQ when compared to the control group. Although the verbal and total IQ scores were lower than in the healthy controls, there was no statistically significant difference.

Table 2 summarizes the WISC-R and SDQ results of the patients and controls, in addition to the PedSQL results of patients and parents.

When the SDQ scores were evaluated, the total difficulties score, where the emotional symptoms, behavioral problems, hyperactivity-attention deficit, and prosocial scale were calculated, of both the DMD and BMD patients was higher when compared to the healthy subjects, which were statistically significant. All of the patients, and patients with DMD in particular, had higher scores in the subsets, such as emotional symptoms, peer problems, and social behavior when compared to the healthy controls, with statistical significance, which indicated that the patients were negatively affected.

Table 2. WISCR scores of the patients and the control group, in addition to the other questionnaires

\begin{tabular}{|c|c|c|c|c|c|}
\hline & $\begin{array}{l}\text { All groups } \\
\mathrm{n}=20\end{array}$ & $\begin{array}{l}\mathrm{DMD} \\
\mathrm{n}=17\end{array}$ & $\begin{array}{l}\text { Control group } \\
(\mathrm{n}=20)\end{array}$ & P-value* & P-value** \\
\hline \multicolumn{6}{|l|}{ WISCR $($ mean \pm SD) } \\
\hline Verbal IQ & $66.8 \pm 18.1$ & $64.7 \pm 12.1$ & $72.1 \pm 11.4$ & 0.152 & 0.092 \\
\hline Performance IQ & $88.5 \pm 23.4$ & $78.9 \pm 14.25$ & $92.2 \pm 14.4$ & 0.615 & 0.004 \\
\hline Total IQ & $72.8 \pm 20.3$ & $69.3 \pm 20.2$ & $74.3 \pm 18.8$ & 0.488 & 0.140 \\
\hline \multicolumn{6}{|l|}{ SDQ scores (mean $\pm \mathrm{SD})$} \\
\hline Total difficulties & $14.5 \pm 9.8$ & $14.2 \pm 9.2$ & $10.9 \pm 4.2$ & 0.003 & 0.003 \\
\hline Emotional symptoms & $3.4 \pm 3.1$ & $3.1 \pm 2.7$ & $2.2 \pm 2.1$ & $<0.001$ & $<0.001$ \\
\hline Behavioral problems & $2.9 \pm 2.7$ & $2.8 \pm 2.5$ & $2.0 \pm 1.6$ & 0.072 & 0.074 \\
\hline Hyperactivity & $4.6 \pm 3.1$ & $4.7 \pm 3.6$ & $3.9 \pm 2.1$ & 0.051 & 0.050 \\
\hline Peer problems & $3.5 \pm 2.9$ & $3.7 \pm 2.8$ & $2.9 \pm 1.8$ & 0.048 & 0.050 \\
\hline Social behavior & $7.1 \pm 3.8$ & $7.2 \pm 3.9$ & $5.8 \pm 2.1$ & $<0.001$ & $<0.001$ \\
\hline \multicolumn{6}{|l|}{ PedsQLchild (mean \pm SD) } \\
\hline Scale summary & $57.7 \pm 16.2$ & $54.6 \pm 22.3$ & $83.6 \pm 12.6$ & $<0.001$ & $<0.001$ \\
\hline Physical health S. & $45.4 \pm 33.4$ & $41.6 \pm 31.2$ & $85.7 \pm 21.2$ & $<0.001$ & $<0.001$ \\
\hline Psychosocial health S. & $64.3 \pm 20.3$ & $61.5 \pm 21.5$ & $83.4 \pm 13.4$ & $<0.001$ & $<0.001$ \\
\hline \multicolumn{6}{|l|}{ PedsQLparent $($ mean \pm SD) } \\
\hline Scale summary & $55.1 \pm 32.3$ & $53.6 \pm 28.5$ & $81.4 \pm 10.1$ & $<0.001$ & $<0.001$ \\
\hline Physical health S. & $56.4 \pm 40.2$ & $55.1 \pm 33.7$ & $80.2 \pm 18.2$ & $<0.001$ & $<0.001$ \\
\hline Psychosocial health S. & $54.4 \pm 33.4$ & $52.9 \pm 31.2$ & $83.4 \pm 11.3$ & $<0.001$ & $<0.001$ \\
\hline
\end{tabular}


PedsQL child-parent scores were lower than the healthy controls in all of the subsets with statistical significance.

\section{Discussion}

This study revealed striking results about the QoL in DMD/BMD patients in our clinic. The QoL in both DMD and in a low number of BMD patients was markedly low when compared to the healthy population. The WHO defines QoL as an individuals' perception of their position in life in the context of the culture and value systems in which they live (10). Health-related quality of life (HRQOL) can be expressed as the patient's subjective perception of dissatisfaction related to his/her own health (11). The QoL of the patients with DMD/BMD has been the subject of many studies. Herein, the results were similar to those of other studies in this area. When compared to healthy children, it was reported that boys with DMD had worse physical and psychosocial HRQOL (12-15). The main end point of the numerous treatment-oriented studies on DMD/BMD has been to increase the QoL of the patients.

One of the few studies that investigated the factors associated with QoL in DMD patients reported that greater subjective fatigue and wheelchair usage was associated with a worsened QoL (12). It is possible that the QoL scores could have been measured as lower than they actually were, since the majority of patients had lost ambulation or required assistance for ambulation.

Cognitive impairment at varying degrees can be found in DMD/BMD patients. A higher prevalence of autism spectrum disorder, anxiety, depression, and obsessive compulsive disorder has been reported in patients with DMD (16). Similarly, behavioral disorders, attention deficit, autism spectrum disorder, and social problems have a higher prevalence in BMD patients (16). Cognitive impairment can be found in one-third of DMD/BMD patients (17).

The mean overall IQ scores of male patients with DMD were observed as 1 SD lower on academic tests when compared to the general population, in addition to an increased incidence of learning difficulties, memory problems, reading problems, and writing and mathematics disorders in these patients (18). In our patient population, the DMD patients had a lower performance on the IQ tests when compared to the healthy controls. Both correct answers and the speed of the answers affect the results in the subtests of performance; hence, weakness due to muscle dystrophy might have decreased the scores.

The updated DMD recommendations state that the SDQ should be applied to all patients. The total difficulties scores in the SDQ of our patients were significantly higher than those of the healthy population. A marked effect in areas such as emotional status, peer problems, and social behavior was observed, both in the overall patient group and in the DMD patients. Perhaps, emotional problems directly negatively affected QoL but it was impossible to determine that in a cross-sectional study. On the other hand, peer problems might have been related to physical disability. Contrary to the literature $(16,18)$, there was no significant difference concerning behavioral problems between the 2 groups. We determined higher scores of the prosocial subscale, which pointed to better social abilities in the patient group, which would be related to not having behavioral problems.

The management of patients with DMD or BMD requires a multidisciplinary team approach that involves neurologists, cardiologists, pulmonologists, endocrinologists, and orthopedists, in addition to rehabilitation teams (physical and occupational therapists, language therapists, and orthotists), psychologists, nutritional experts, and social services. This study emphasized the importance of defining difficulties using the SDQ, and evaluating and taking action to ameliorate the QoL. It is necessary to consider the emotional and social effects of academic failure and provide early support in this area.

One of the most important limitations of this prospective study was the limited number of patients and lack of clinical and genetic homogeneity. Although the disease is the result of a mutation in the dystrophin gene, mutations can vary and clinical features depend on the type of mutation. It is very difficult to achieve clinical and genetic homogeneity in these rare diseases. In the future, a better evaluation of cognitive and social outcomes of these diseases can be achieved with increased patient homogeneity via international multicentric studies or studies based on international NMD databases involving a greater number of patients. In these diseases, which have a longer life expectancy due to improved health care, 
although there is no definitive cure, the emphasis on QoL has a great importance in patient management.

Acknowledgments: All authors thank all the patients and family members for their participation in this study.

\section{Ethics}

Ethics Committee Approval: Ethics committee approval was obtained from the institutional ethics board of the Ankara Children's Hematology-Oncology Training and Research Hospital Ethics Committee (2018-2003).

Conflict of Interest: No conflict of interest was declared by the authors.

Financial Disclosure: The authors declared that this study received no financial support.

\section{References}

1. Birnkrant DJ, Bushby K, Bann CM, Alman BA, Apkon SD, Blackwell A, et al. Diagnosis and management of Duchenne muscular dystrophy, part 2: respiratory, cardiac, bone health, and orthopaedic management. Lancet Neurol. 2018 Apr;17(4):34761. 1https://doi.org/10.1016/S1474-4422(18)30025-5.

2. Le Rumeur E. Dystrophin and the two related genetic diseases, Duchenne and Becker muscular dystrophies. Bosn J Basic Med Sci [Internet]. 2015 Jul 20 [cited 2020 Apr 30];15(3). https://doi. org/10.17305/bjbms.2015.636.

3. Trout CJ, Case LE, Clemens PR, McArthur A, Noritz G, Ritzo M, et al. A Transition Toolkit for Duchenne Muscular Dystrophy. Pediatrics. 2018 Oct;142(Supplement 2):S110-7. https://doi. org/10.1542/peds.2018-0333M.

4. Felisari G, Boneschi FM, Bardoni A, Sironi M, Comi GP, Robotti $\mathrm{M}$, et al. Loss of Dp140 dystrophin isoform and intellectual impairment in Duchenne dystrophy. Neurology. 2000 Aug 22;55(4):559-64. https://doi.org/10.1212/WNL.55.4.559.

5. Wechsler D. Wechsler Intelligence Scale for Children. San Antonio, TX, US: Psychological Corporation; 1949. (Wechsler Intelligence Scale for Children).

6. Savaşır I, Şahin N. Wechsler çocuklar için zeka ölçeği (WISC-R) uygulama kitapçı̆̆ı. Türk Psikologlar Derneği Ank. 1995.

7. Goodman R. The Strengths and Difficulties Questionnaire: a research note. J Child Psychol Psychiatry. 1997 Jul;38(5):581-6. https://doi.org/10.1111/j.1469-7610.1997.tb01545.x.

8. Güvenir T, Özbek A, Baykara B, Arkar H, Şentürk B, İncekaş S. (2008). Güçler ve Güçlükler Anketi'nin (GGA) Türkçe uyarlamasının psikometrik özellikleri. Çocuk ve Gençlik Ruh Sağlığ Dergisi. 15(2):65-74.

9. Varni JW, Seid M, Kurtin PS. Pediatric health-related quality of life measurement technology: A guide for health care decision makers. J Clin Outcomes Manag. 1999a;6:33-40.

10. The World Health Organization Quality of Life assessment (WHOQOL): position paper from the World Health Organization. Soc Sci Med 1982. 1995 Nov;41(10):1403-9. https://doi. org/10.1016/0277-9536(95)00112-k.

11. Study protocol for the World Health Organization project to develop a Quality of Life assessment instrument (WHOQOL). Qual Life Res Int J Qual Life Asp Treat Care Rehabil. 1993 Apr;2(2):153-9.

12. Factors Associated With Health-Related Quality of Life in Children With Duchenne Muscular Dystrophy - Yi Wei, Kathy Nixon Speechley, Guangyong Zou, Craig Campbell, 2016 [Internet]. [cited 2020 Apr 30]. Available from: https://journals. sagepub.com/doi/abs/10.1177/0883073815627879.

13. McDonald CM, McDonald DA, Bagley AM, Sienko-Thomas S, Buckon C, Henricson E, et al. Relationship Between Clinical Outcome Measures and Parent Proxy Reports of Health-related Quality of Life in Ambulatory Children with Duchenne Muscular Dystrophy. J Child Neurol. 2010 Sep;25(9):1130-44. https://doi. org/10.1177/0883073810371509.

14. Davis SE, Hynan LS, Limbers CA, Andersen CM, Greene MC, Varni JW, et al. The PedsQL in pediatric patients with Duchenne muscular dystrophy: feasibility, reliability, and validity of the Pediatric Quality of Life Inventory Neuromuscular Module and Generic Core Scales. J Clin Neuromuscul Dis. 2010 Mar;11(3):97109. https://doi.org/10.1097/CND.0b013e3181c5053b.

15. Uzark K, King E, Cripe L, SpicerR, Sage J,Kinnett K, et al.Healthrelated quality of life in children and adolescents with Duchenne muscular dystrophy. Pediatrics. 2012 Dec;130(6):e1559-1566. https://doi.org/10.1542/peds.2012-0858.

16. Hellebrekers DMJ, Lionarons JM, Faber CG, Klinkenberg S, Vles JSH, Hendriksen JGM. Instruments for the Assessment of Behavioral and Psychosocial Functioning in Duchenne and Becker Muscular Dystrophy; a Systematic Review of the Literature. J Pediatr Psychol. 2019 01;44(10):1205-23. https:// doi.org/10.1093/jpepsy/jsz062.

17. Bresolin N, Castelli E, Comi GP, Felisari G, Bardoni A, Perani D, et al. Cognitive impairment in Duchenne muscular dystrophy. Neuromuscul Disord. 1994 Jul 1;4(4):359-69. https://doi. org/10.1016/0960-8966(94)90072-8.

18. Banihani R, Smile S, Yoon G, Dupuis A, Mosleh M, Snider A, et al. Cognitive and Neurobehavioral Profile in Boys With Duchenne Muscular Dystrophy. J Child Neurol. 2015 Oct;30(11):1472-82. https://doi.org/10.1177/0883073815570154. 